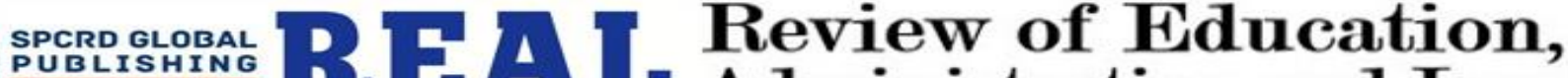 Administration and Law
}

Journal homepage: http://real.spcrd.org ISSN (Print): 2708-1788

ISSN (Online): 2708-3667

\section{Factors Affecting Human Capital in Southern Punjab: An Empirical Analysis}

\author{
a Salyha Zulfiqar Ali Shah, ${ }^{b}$ Imran Sharif Chaudhry, ${ }^{c}$ Fatima Farooq \\ ${ }^{a}$ Assistant Professor, School of Economics, Bahauddin Zakariya University Multan, Pakistan \\ Email: salyhazulfiqar@bzu.edu.pk \\ ${ }^{\mathrm{b}}$ Dean of Arts \& Social Sciences / Director, School of Economics, Bahauddin Zakariya University Multan, Pakistan \\ Email: imran@bzu.edu.pk \\ ${ }^{c}$ Associate Professor, School of Economics, Bahauddin Zakariya University Multan, Pakistan \\ Email: fatimafarooq@bzu.edu.pk
}

\begin{tabular}{ll}
\hline ARTICLE DETAILS & ABSTRACT \\
\hline History: & $\begin{array}{l}\text { Analyzing the factors affecting human capital at household level } \\
\text { Accepted 13 March 2021 }\end{array}$ \\
increases the productivity of people living in developing countries. A \\
primary data was collected through a household survey to study the \\
factors affecting human capital in Southern Punjab using Ordinary Least \\
Keywords: & Squares (OLS) regression technique. The findings show that the location \\
Human Capital; Southern & of the household in rural areas, occupation of the household head in the \\
Punjab; Education; Health & primary sector, household size, household poverty and female/male \\
& ratio shows significant and negatively affecting the human capital of the \\
JEL Classification: & households in Southern Punjab. Moreover, per capita income, number of \\
I1, I2, P46 & earners in the household, remittances are significant and positively \\
& affecting the human capital of the households in Southern Punjab. The \\
annual budget allocation for education in Pakistan is very low, so & Government should allocate a significant amount of funds to the \\
DOI: 10.47067/real.v4i1.124 & education sector.
\end{tabular}

(C) 2021 The authors. Published by SPCRD Global Publishing. This is an open access article under the Creative Commons AttributionNonCommercial 4.0

Corresponding author's email address: imran@bzu.edu.pk

\section{Introduction}

Numerous studies stated that education affects human capital formation which positively and directly affects the income of the individuals or workers. It generates a trickledown effect when economic growth is generated through investment in education and health, which further stimulate economic growth, reduce poverty and unequal distribution of income in less developed countries. Lucas (1988) and Romer (1986) explained the importance of investing in human capital as it will further contribute to accelerating economic development and reducing poverty. This accelerates the per capita income of the household and ultimately saving them from the vicious circle of poverty. Therefore, as educational qualifications increase, the economic participation of the individuals also increases. The present study focuses on Southern Punjab, which comprises of 3 divisions. It is a mainly a developing and backward region of the Punjab. Considering the problem of lack of human capital in Southern 
Punjab, this study attempts to analyze the factors affecting human capital. These divisions have received very minute prosperity both at the policy and empirical level.

This paper is summarized as follows. Section 2 presents the review of past and current piece of literature. Section 3 presents data and methodology. Section 4 explain the empirical findings. In section 5 the concluding remarks are presented.

\section{The Literature Review}

This section focuses on the studies of human capital by different researchers in different periods. Barro and Lee, (1993) presented that male education attainment was the key to achieve economic growth. A study by Barro and Lee, (1993) showed that investment as a ratio to GDP and secondary school attainments shows a great positive influence on economic growth. Becker (1995) analyzed that effective utilization of trained persons and efficient working of the organization and an active economic system would be crucial factors for sustainable economic growth.

Oketch (2006) has used the Two Stages Least Squares (2SLS) technique in Africa to measure the role of human capital in economic growth. The author had used three models, using alternatively GDP per capita, physical capital and human capital as dependent variables. The study concluded that physical capital and human capital are very crucial for the development of African countries.

McFadden (2008) discussed the concept of human capital and its wear and tear with time. The author revived T.W. Schultz's definition of human capital as it is the stock of knowledge education, selfimprovement and on the job training. Health can be denoted by strength, stamina, longevity, acuity, vitality and vigor. The author concluded that health capital can be discussed in cardiovascular capital and cognitive capital. Fluid intelligence increase by the year 14 and later diminished. However, crystallized intelligence increases and decreases after 65 years of age.

Lee and Francisco (2010) analyzed the correlates of human capital in emerging Asia. Parent's income and education, income distribution, number of children, government policy and ethics were discussed in the study. The study concluded that the parent's income and education would improve the child's education. The higher the education of females, the lower will be the fertility rates. Lowerincome inequality and diminishing fertility rates would improve the economic conditions of East Asia.

Lee and Lee (2016) studied cross country data of 111 countries, during the year 1820-1945 and 1870 to 2010. The authors have collected data from United Nations Educational, Scientific and Cultural Organization (UNESCO) publications. The duration of schooling represents the human capital stock. The study concluded that in the long run, an increase in educational attainment will accelerate human capital across the countries. Gender inequality regarding education has been reduced considerably across different regions.

Wang et al. (2016) studied the household's characteristics from six counties in Shaanxi province, China. The study showed that educated people tend to work in off-farm occupations. Educated migrants were more likely to work as professional managers, otherwise, their choice would be self-employed/job or lastly skilled work. Migrants or stayers having any training programs are more likely to find a good managerial job. 
Blanchard and Olney (2017) examined the relationship between trade and human capital. The author has discussed the demand side of human capital in various countries. The study revealed that those who undergone worked in the high skill-intensive sector more will more likely to invest in education. However, those who worked in the low intensive sector will have more drop out of education and are illiterate.

\section{Data and Methodology}

The sample size consists of 1068 observations, collected during the year 2019. The primary data has been collected through a household survey in Southern Punjab, adopted simple random and stratified sampling technique.

\subsection{Measuring Human Capital}

The human capital comprises of education, health, skills, on-the-job training of the respondent that contribute significantly to the human capital of the household. For this purpose, a household human capital index is constructed by employing a useful technique to evaluate the factors affecting the human capital of the household in Southern Punjab. The present study has employed Principal Component Analysis (PCA) to assign weights to indicator variables (Jolliffe and Cadima, 2016). The principal component analysis then selects the factors or indicators with eigenvalues of more than 0.75 .

The loadings of factors, variables of the human capital are calculated by using the Principal Component Analysis (PCA). The Principal Component Analysis (PCA) presents the calculation of standardized values of variables and evaluates the eigenvalues that refer to the variance of the factors and then these values can be used to determine the components. (Fukuda-Parr, 2006; Alkire et al., 2013; Abrarul-haq, Jali and Islam, 2016).

In the present study, the Human Capital index was constructed by employing these indicators related to the education and health of the respondent. These indicators are, education of the household head, access to school, on the job training, age of the household head, skills acquired, mental or physical disability, access to the health unit and distance to the health unit. In the present study, the Human Capital Index is constructed as a proxy for human capital and utilized as a dependent variable to analyze the econometric results of human capital in this study.

\subsection{Regression Model}

The study used the Ordinary Least Squares (OLS) regression technique. The regression model can be explained through the equation

$$
\mathrm{Y}^{*}=\beta_{1}+\beta_{2} \mathrm{X} 2 \mathrm{i}+\beta_{3} \mathrm{X} 3 \mathrm{i}+\ldots \ldots \ldots \ldots \ldots \ldots+\beta_{\mathrm{k}} \mathrm{X}_{\mathrm{ki}}+\epsilon_{\mathrm{i}}
$$

$\mathrm{Y}^{*}$ is the dependent variable representing the human capital of the household and Xs are the various socioeconomic and demographic indicators that determine the human capital at the household level in Southern Punjab. 
Table 1: Variables Utilized for OLS Regression Estimates of Human Capital

\begin{tabular}{|c|c|c|}
\hline Variables & & Description of the Variables \\
\hline \multicolumn{3}{|c|}{ Dependent Variable } \\
\hline $\mathrm{HCI}$ & Human Capital Index & $\begin{array}{l}\text { It is the proxy for Human Capital. It an index constructed } \\
\text { by considering the household's education and health- } \\
\text { related factors. }\end{array}$ \\
\hline \multicolumn{3}{|c|}{ Independent Variables } \\
\hline LNPCI & Log of Per Capita Income & $\begin{array}{l}\text { It is the proxy for Economic Development. It is the natural } \\
\text { log of per capita income. }\end{array}$ \\
\hline $\mathrm{Y}$ & Household Poverty & $\begin{array}{l}=1 \text { if per capita income is lower than } \$ 1.90 / \text { day then the } \\
\text { household is Poor } \\
=0 \text { if per capita income more than } \$ 1.90 / \text { day then the } \\
\text { household is Non-Poor }\end{array}$ \\
\hline HSIZE & Household 's Size & The total person in a household \\
\hline FMR & Female/Male Ratio & $\begin{array}{l}\text { The total number of females divided by the total number of } \\
\text { males in the household }\end{array}$ \\
\hline OCC & $\begin{array}{l}\text { Occupation of Household } \\
\text { Head }\end{array}$ & $\begin{array}{l}=1 \text { if household head working in the primary sector } \\
=0 \text { if household head not working in the primary sector }\end{array}$ \\
\hline NOEIH & Number of Earners & The household comprising of total earners \\
\hline REM & Remittances & $\begin{array}{l}=1 \text { if household is receiving remittances } \\
=0 \text { if household is not receiving remittances }\end{array}$ \\
\hline LOC & Location & $\begin{array}{l}=1 \text { if a residential area is rural } \\
=0 \text { if a residential area is urban }\end{array}$ \\
\hline
\end{tabular}

\subsection{Human Capital model}

$H C I=f(L O C, H S I Z E, F M R, O C C, Y, L n P C I, N O E I H, R E M)$

The above model is the specification of the Human Capital Index (HCI) employing the Ordinary Least Squares (OLS) regression technique. The human capital is the dependent variable in the present analysis.

\section{Empirical Findings}

Table 2: Descriptive Analysis of Human Capital in Southern Punjab

\begin{tabular}{|l|c|c|}
\hline \multicolumn{1}{|c|}{ Variables } & Mean & Standard Deviation \\
\hline Human Capital Index & 6.86 & 2.95 \\
\hline Per Capita Income & 9864.6 & 7730 \\
\hline Poverty & 0.40 & 0.49 \\
\hline Household Size & 6.34 & 2.55 \\
\hline Number of Earners in the Household & 2.04 & 1.07 \\
\hline Occupation of the Household Head & 0.57 & 0.50 \\
\hline Location & 0.77 & 0.42 \\
\hline Remittances & 0.12 & 0.32 \\
\hline Female/Male Ratio & 1.33 & 0.86 \\
\hline
\end{tabular}

Source: Survey data, 2019 
Table 3: Correlation Analysis of Human Capital and its Correlates

\begin{tabular}{|c|c|c|c|c|c|c|c|c|c|}
\hline Variables & HCY & LOC & NOEIH & OCC & $\mathbf{Y}$ & REM & SIZE & FMR & PCI \\
\hline HCY & 1.000 & & & & & & & & \\
\hline LOC & $\begin{array}{c}-0.258 \\
(0.000) \\
\end{array}$ & 1.000 & & & & & & & \\
\hline NOEIH & $\begin{array}{c}0.497 \\
(0.000)\end{array}$ & $\begin{array}{c}-0.189 \\
(0.000)\end{array}$ & 1.000 & & & & & & \\
\hline OCC & $\begin{array}{c}-0.475 \\
(0.000)\end{array}$ & $\begin{array}{c}0.277 \\
(0.000)\end{array}$ & $\begin{array}{c}-0.090 \\
(0.003)\end{array}$ & 1.000 & & & & & \\
\hline $\mathbf{Y}$ & $\begin{array}{c}-0.604 \\
(0.000) \\
\end{array}$ & $\begin{array}{c}0.095 \\
(0.002) \\
\end{array}$ & $\begin{array}{c}-0.181 \\
(0.000) \\
\end{array}$ & $\begin{array}{c}0.469 \\
(0.000)\end{array}$ & 1.000 & & & & \\
\hline REM & $\begin{array}{c}0.280 \\
(0.000)\end{array}$ & $\begin{array}{c}-0.130 \\
(0.000) \\
\end{array}$ & $\begin{array}{c}0.227 \\
(0.000) \\
\end{array}$ & $\begin{array}{c}-0.118 \\
(0.000)\end{array}$ & $\begin{array}{c}-0.216 \\
(0.000)\end{array}$ & 1.000 & & & \\
\hline HSIZE & $\begin{array}{c}-0.181 \\
(0.000)\end{array}$ & $\begin{array}{l}-0.028 \\
(0.363)\end{array}$ & $\begin{array}{c}0.469 \\
(0.000)\end{array}$ & $\begin{array}{c}0.089 \\
(0.004)\end{array}$ & $\begin{array}{c}0.238 \\
(0.000)\end{array}$ & $\begin{array}{c}0.010 \\
(0.744)\end{array}$ & 1.000 & & \\
\hline FMR & $\begin{array}{c}0.198 \\
(0.000)\end{array}$ & $\begin{array}{c}0.035 \\
(0.255)\end{array}$ & $\begin{array}{c}0.151 \\
\text { (0.000) }\end{array}$ & $\begin{array}{c}-0.126 \\
(0.000)\end{array}$ & $\begin{array}{c}-0.233 \\
(0.000)\end{array}$ & $\begin{array}{c}0.092 \\
(0.003)\end{array}$ & $\begin{array}{c}-0.117 \\
(0.000)\end{array}$ & 1.000 & \\
\hline PCI & $\begin{array}{c}0.529 \\
(0.000) \\
\end{array}$ & $\begin{array}{l}-0.098 \\
(0.001) \\
\end{array}$ & $\begin{array}{c}0.141 \\
(0.000) \\
\end{array}$ & $\begin{array}{c}-0.411 \\
(0.000) \\
\end{array}$ & $\begin{array}{c}-0.643 \\
(0.000) \\
\end{array}$ & $\begin{array}{c}0.180 \\
(0.000) \\
\end{array}$ & $\begin{array}{c}-0.226 \\
(0.000) \\
\end{array}$ & $\begin{array}{c}0.125 \\
(0.000) \\
\end{array}$ & 1.000 \\
\hline
\end{tabular}

Source: Survey data, 2019; p-values in the bracket

Table 4 presents the factors affecting the human capital of the household in Southern Punjab. The human capital index is constructed as a proxy for human capital and employed as a dependent variable for the econometric analysis of the present study.

An increase in the number of earners in the household by one member will increase the human capital index or human capital of a household by 1.484 units. results are also concluded by Ali et al., (2012). If the occupation of the respondent in the primary sector increases by one unit, it will lead to reducing the human capital index or human capital by 1.148 units. Poor households mostly work in the primary sector (Mukherjee and Benson, 1998).

If the poverty of the household increases by one unit, it will lead to reducing the human capital index or human capital by 0.780 units. Poor households have limited resources and low per capita income. The same findings are concluded by Attanasio et al., (2017). The remittances received by the household increases by one unit, which will lead to an increase in the human capital index or human capital by 0.485 units. This study supports the finding of Acharya and Gonzalez (2014) and Hines and Simpson (2019). It has been observed that if the income per capita of the household increases by one percent, it will lead to an increase in the human capital index or human capital of the household by o.885 units [Mincer (1981), Benhabib and Speigel (1994)]. An increase in household size by one person will result in falling the human capital index or human capital by 0.380 units. The results of the present study support the findings concluded earlier by Downey (2001). If the female/male ratio increases by 1unit, it will lead to reducing the human capital index or human capital by 0.125 units respectively.

The results from the econometric analysis show that the coefficient of the location of the household in a rural area shows a negative relationship with the human capital index or human capital 
of the household, significant statistically at a 1 percent significance level. If the location of the household in the rural area increases by one unit, then it leads to a decrease in the human capital index or human capital of the household by 0.334 units. [Jung and Thorbecke (2003) and Zhang (2014.

Table 4 Econometric Analysis of Factors Affecting Human Capital in Southern Punjab

\begin{tabular}{|c|c|c|c|c|}
\hline \multicolumn{5}{|c|}{ Dependent Variable: Human Capital Index (HCI) } \\
\hline Variable & Coefficients & $\begin{array}{c}\text { Standard } \\
\text { Errors }\end{array}$ & t-Statistic & p-value \\
\hline C & -0.316 & 1.300 & -0.243 & 0.808 \\
\hline Number of Earners in the Household & 1.484 & 0.062 & 23.833 & 0.000 \\
\hline Occupation of the Household Head & -1.148 & 0.129 & -8.930 & 0.000 \\
\hline Poverty & -0.780 & 0.197 & -3.956 & 0.000 \\
\hline Remittances & 0.485 & 0.169 & 2.875 & 0.004 \\
\hline Per Capita Income & 0.885 & 0.133 & 6.654 & 0.000 \\
\hline Household Size & -0.380 & 0.026 & -14.650 & 0.000 \\
\hline Female/Male Ratio & -0.125 & 0.063 & -1.998 & 0.046 \\
\hline Location & -0.334 & 0.132 & -2.539 & 0.011 \\
\hline R-squared & 0.678 & \multicolumn{2}{|c|}{ Adjusted R-squared } & 0.676 \\
\hline F-statistic & 278.420 & \multicolumn{2}{|c|}{ Prob(F-statistic) } & (0.000) \\
\hline \multicolumn{5}{|c|}{ Diagnostic Test: Heteroskedasticity White Test } \\
\hline F-statistic & 1.385 & \multicolumn{2}{|c|}{ Prob. F(40,1026) } & 0.112 \\
\hline Obs*R-squared & 262.860 & \multicolumn{2}{|c|}{ Prob. Chi-Square(40) } & 0.121 \\
\hline
\end{tabular}

Source: Survey data, 2019

Table 5 presents the OLS regression results of the factors affecting human capital in Multan Division. An increase in the number of earners in the household by one member will result from an increase in the human capital index or human capital by 1.539 units [Ackah (2013)]. If the occupation of the respondent in the primary sector increases, it will lead to reduce the human capital index or human capital of a household by 1.446 units [(Mukherjee and Benson, 1998)]. If the poverty of the household increases by one unit, it will reduce the human capital index or human capital of a household by 0.942 units. \{Becker (1995), Warren, et al., (2001)\}. If the foreign remittances increase by one unit, this increase the human capital index or human capital of the household by 0.661 units [Bansak and Chezum (2009). If the per capita income of the household increases by one percent, the human capital index or human capital of a household increase by 0.616 units. [Olaniyan and Okemakinde (2008). An increase in household size by one person will reduce the human capital index or human capital of a household by 0.400 units. If the female/male ratio increases by 1unit, it will decrease the human capital index or human capital of the household by 0.230 units [Knowles et al., (2002)]. 
Table 5: Econometric Analysis of Factors Affecting Human Capital in Multan Division

\begin{tabular}{|c|c|c|c|c|}
\hline \multicolumn{5}{|c|}{ Dependent Variable: Human Capital Index (HCI) } \\
\hline Variables & Coefficients & $\begin{array}{l}\text { Standard } \\
\text { Errors }\end{array}$ & t-Statistic & P-value \\
\hline Constant & 2.443 & 2.312 & 1.057 & 0.291 \\
\hline Number of Earners in the Household & 1.539 & 0.116 & 13.236 & 0.000 \\
\hline Occupation of the Household Head & -1.466 & 0.237 & -6.174 & 0.000 \\
\hline Poverty & -0.942 & 0.382 & -2.465 & 0.014 \\
\hline Remittances & 0.661 & 0.309 & 2.139 & 0.033 \\
\hline Per Capita Income & 0.616 & 0.236 & 2.614 & 0.009 \\
\hline Household Size & -0.400 & 0.047 & -8.431 & 0.000 \\
\hline Female/Male Ratio & -0.230 & 0.117 & -1.961 & 0.051 \\
\hline Location & -0.319 & 0.237 & -1.346 & 0.179 \\
\hline R-squared & 0.639 & \multicolumn{2}{|c|}{ Adjusted R-squared } & 0.631 \\
\hline F-statistic & 81.155 & \multicolumn{2}{|c|}{ Prob(F-statistic) } & $(0.000)$ \\
\hline \multicolumn{5}{|c|}{ Diagnostic Test: Heteroskedasticity White Test } \\
\hline F-statistic & 1.297 & \multicolumn{2}{|c|}{ Prob. F(40,335) } & 0.125 \\
\hline Obs*R-squared & 80.935 & \multicolumn{2}{|c|}{ Prob. Chi-Square (40) } & 0.132 \\
\hline
\end{tabular}

Source: Survey data, 2019

Table 6 presents the OLS regression results of the factors affecting human capital in Bahawalpur division. An increase in the number of an earner in the household by one person will increase the human capital index or human capital by 1.338 units. If the occupation of the respondent in the primary sector increases by one unit, the human capital index or human capital of a household decreases by 1.096 units. [Sumberg et al. (2004)]. If the poverty of the household is inclined by one unit, it will reduce the human capital index or human capital of the household by 0.759 units [Chen and Wang (2001), Handa et al., (2005)]. If the income per capita of the household increases by one percent, the human capital index or human capital of the household will raise by 1.221 units [Mincer (1981), Benhabib and Speigel (1994)]. An increase in household size by one person will result in falling the human capital index or human capital of a household by 0.324 units. If the location of the household in the rural area increases, then it leads to a decrease in the human capital index or human capital of the household by 0.413 units. [Aref (2011) and Zhang (2014)]. 
Table 6: Econometric Analysis of Factors Affecting Human Capital in Bahawalpur Division

\begin{tabular}{|l|c|c|c|c|}
\hline \multicolumn{5}{|c|}{ Dependent Variable: Human Capital Index (HCI) } \\
\hline Variable & Coefficients & $\begin{array}{c}\text { Standard } \\
\text { Errors }\end{array}$ & t-Statistic & P-value \\
\hline C & -3.330 & 2.275 & -1.464 & 0.144 \\
\hline Number of Earners in the Household & 1.338 & 0.100 & 13.391 & 0.000 \\
\hline Occupation of the Household Head & -1.096 & 0.213 & -5.141 & 0.000 \\
\hline Poverty & -0.759 & 0.333 & -2.277 & 0.023 \\
\hline Remittances & 0.190 & 0.259 & 0.733 & 0.464 \\
\hline Per Capita Income & 1.221 & 0.232 & 5.252 & 0.000 \\
\hline Household Size & -0.324 & 0.042 & -7.652 & 0.000 \\
\hline Female/Male Ratio & -0.078 & 0.101 & -0.778 & 0.437 \\
\hline Location & -0.413 & 0.207 & -1.991 & 0.047 \\
\hline R-squared & 0.723 & Adjusted R-squared & 0.716 \\
\hline F-statistic & 112.056 & Prob (F-statistic) & $(0.000)$ \\
\hline Diagnostic Test: Heteroskedasticity White Test & \multicolumn{3}{|l|}{} \\
\hline F-statistic & 1.477 & Prob. F (40,312) & 0.114 \\
\hline Obs*R-squared & 108.844 & Prob. Chi-Square (40) & 0.127 \\
\hline
\end{tabular}

Source: Survey data, 2019

Table 7 presents the OLS regression results of the factors affecting human capital in in D.G. Khan division. an increase in the number of earners in the household by one member will increase the human capital index or human capital of the household by 1.601 units [Nguyen, et al., (2004)]. If the occupation of the household head in the primary sector increases by one unit, the human capital index or human capital of the household reduces by 0.827 units [Mukherjee and Benson (1998)]. If the poverty of the household increases by one unit, it will lead to reducing the human capital index or human capital of a household by 0.588 units. [Attanasio et al., (2017)]. It is found that if the remittances received by the household increase by one unit, it will lead to an increase in the human capital index or human capital by 0.544 units, significant statistically at a 10 percent significance level [Azam and Raza (2016)]. If the per capita income of the household increases by one percent, the human capital index or human capital of the household will increase by 0.876 units. [Benhabib and Speigel (1994), Knowles and Owen (1995)]. An increase in household size by one person will decrease the human capital index or human capital by o.419 units [Downey (1995)]. 
Table 7: Econometric Analysis of Factors Affecting Human Capital in D.G. Khan Division

\begin{tabular}{|l|c|c|c|c|}
\hline \multicolumn{5}{|c|}{ Dependent Variable: Human Capital Index (HCI) } \\
\hline Variable & Coefficients & $\begin{array}{c}\text { Standard } \\
\text { Errors }\end{array}$ & t-Statistic & p-value \\
\hline C & -0.692 & 2.184 & -0.317 & 0.752 \\
\hline Number of Earners in the Household & 1.601 & 0.108 & 14.774 & 0.000 \\
\hline Occupation of the Household Head & -0.827 & 0.215 & -3.847 & 0.000 \\
\hline Poverty & -0.588 & 0.314 & -1.872 & 0.062 \\
\hline Remittances & 0.544 & 0.315 & 1.730 & 0.085 \\
\hline Per Capita Income & 0.876 & 0.225 & 3.896 & 0.000 \\
\hline Household Size & -0.419 & 0.045 & -9.288 & 0.000 \\
\hline Female/Male Ratio & -0.078 & 0.107 & -0.728 & 0.467 \\
\hline Location & -0.217 & 0.242 & -0.895 & 0.372 \\
\hline R-squared & 0.695 & Adjusted R-squared & 0.688 \\
\hline F-statistic & 93.815 & Prob(F-statistic) & $(0.000)$ \\
\hline Diagnostic Test: Heteroskedasticity White Test & \multicolumn{4}{|l|}{} \\
\hline F-statistic & 1.715 & Prob. F((40,297) & 0.104 \\
\hline Obs*R-squared & 182.503 & Prob. Chi-Square(40) & 0.118 \\
\hline
\end{tabular}

Source: Survey data, 2019 
Table 8: Comparative Analysis of Factors Affecting Human Capital in Southern Punjab and its Division.

\begin{tabular}{|c|c|c|c|c|}
\hline \multicolumn{5}{|c|}{ Dependent Variable: Human Capital INDEX(HCI) } \\
\hline Variable & $\begin{array}{c}\text { Coefficients } \\
\text { Multan Division }\end{array}$ & $\begin{array}{c}\text { Coefficients } \\
\text { Bahawalpur } \\
\text { Division }\end{array}$ & $\begin{array}{c}\text { Coefficients } \\
\text { D.G. Khan } \\
\text { Division }\end{array}$ & $\begin{array}{c}\text { Coefficients } \\
\text { Southern } \\
\text { Punjab }\end{array}$ \\
\hline Constant & 2.443 & -3.330 & -0.692 & -0.316 \\
\hline $\begin{array}{l}\text { Number of Earners in the } \\
\text { Household }\end{array}$ & $\begin{array}{c}1.539 \\
* *(0.000) \\
\{0.116\} \\
\end{array}$ & $\begin{array}{c}1.338 \\
* *(0.000) \\
\{0.100\} \\
\end{array}$ & $\begin{array}{c}1.601 \\
* *(0.000) \\
\{0.108\} \\
\end{array}$ & $\begin{array}{c}1.484 \\
* *(0.000) \\
\{0.062\} \\
\end{array}$ \\
\hline Occupation of the Household Head & $\begin{array}{c}-1.466 \\
* *(0.000) \\
\{0.237) \\
\end{array}$ & $\begin{array}{c}-1.096 \\
* *(0.000) \\
\{0.213) \\
\end{array}$ & $\begin{array}{c}-0.827 \\
* *(0.000) \\
\{0.215) \\
\end{array}$ & $\begin{array}{c}-1.148 \\
* *(0.000) \\
\{0.129\} \\
\end{array}$ \\
\hline Poverty & $\begin{array}{c}-0.942 \\
*(0.014) \\
\{0.382\} \\
\end{array}$ & $\begin{array}{c}-0.759 \\
*(0.023) \\
\{0.333\}\end{array}$ & $\begin{array}{c}-0.588 \\
* * *(0.062) \\
\{0.314\} \\
\end{array}$ & $\begin{array}{c}-0.780 \\
* *(0.000) \\
\{0.197\} \\
\end{array}$ \\
\hline Remittances & $\begin{array}{c}0.661 \\
*(0.033) \\
\{0.309\} \\
\end{array}$ & $\begin{array}{c}0.190 \\
(0.464) \\
\{0.259\} \\
\end{array}$ & $\begin{array}{c}0.544 \\
* * *(0.085) \\
\{0.315\} \\
\end{array}$ & $\begin{array}{c}0.485 \\
* *(0.004) \\
\{0.169\} \\
\end{array}$ \\
\hline Per Capita Income & $\begin{array}{c}0.616 \\
* *(0.009) \\
\{0.236\} \\
\end{array}$ & $\begin{array}{c}1.221 \\
* *(0.000) \\
\{0.232\} \\
\end{array}$ & $\begin{array}{c}0.876 \\
* *(0.000) \\
\{0.225\} \\
\end{array}$ & $\begin{array}{c}0.885 \\
* *(0.000) \\
\{0.133\} \\
\end{array}$ \\
\hline Household Size & $\begin{array}{c}-0.400 \\
* *(0.000) \\
\{0.047\} \\
\end{array}$ & $\begin{array}{c}-0.324 \\
* *(0.000) \\
\{0.042\} \\
\end{array}$ & $\begin{array}{c}-0.419 \\
* *(0.000) \\
\{0.045\} \\
\end{array}$ & $\begin{array}{c}-0.380 \\
* *(0.000) \\
\{0.026\} \\
\end{array}$ \\
\hline Female/Male Ratio & $\begin{array}{c}-0.230 \\
* * *(0.051) \\
\{0.117\} \\
\end{array}$ & $\begin{array}{l}-0.078 \\
(0.437) \\
\{0.101\} \\
\end{array}$ & $\begin{array}{l}-0.078 \\
(0.467) \\
\{0.107\}\end{array}$ & $\begin{array}{c}-0.125 \\
*(0.046) \\
\{0.063\} \\
\end{array}$ \\
\hline Location & $\begin{array}{l}-0.319 \\
(0.179) \\
\{0.237\}\end{array}$ & $\begin{array}{c}-0.413 \\
*(0.047) \\
\{0.207\}\end{array}$ & $\begin{array}{l}-0.217 \\
(0.372) \\
\{0.242\}\end{array}$ & $\begin{array}{c}-0.334 \\
*(0.011) \\
\{0.132\}\end{array}$ \\
\hline R-squared & 0.639 & 0.723 & 0.695 & 0.678 \\
\hline Adjusted R-squared & 0.631 & 0.716 & 0.688 & 0.676 \\
\hline $\begin{array}{l}\text { F-statistic } \\
\text { Prob(F-statistic) }\end{array}$ & $\begin{array}{c}81.155 \\
(0.000)\end{array}$ & $\begin{array}{l}112.056 \\
(0.000)\end{array}$ & $\begin{array}{l}93.815 \\
(0.000) \\
\end{array}$ & $\begin{array}{l}278.420 \\
(0.000)\end{array}$ \\
\hline
\end{tabular}

Source: Survey data, 2019.

Note: The p-values in the brackets and parenthesis are standard error values respectively.

* 5 percent level of Significance,

$* * 1$ percent level of Significance,

$* * * 10$ percent level of Significance,

\section{Concluding Remarks}

This paper explains the factors affecting the human capital of the households in Southern Punjab and its three divisions. The sample size consists of 1068 households. For econometric analysis, the Ordinary Least Squares (OLS) techniques have been employed to examine the results. The dependent 
variable is the Human Capital Index (HDI), which is used as a proxy for the human capital of the household.

It is concluded from the econometric analysis that the location of the household in rural areas, occupation of the household head in the primary sector, household size, household poverty and female/male ratio shows significant and negatively affecting the human capital of the households in Southern Punjab. Moreover, per capita income, remittances, number of earners in the household are significant and positively affecting the human capital of the households in Southern Punjab.

Greater attention should be given to reduce the "Knowledge Gap" in those areas specifically rural, where the facilities of education, especially primary education are inadequate. Long term private and public loans to students are warranted. Therefore, investment in human capital for a secondary and higher level of education is highly significant for the people belonging to the poor and underdeveloped regions like Southern Punjab. Human capital embodied labor effects positively and significantly to economic growth, so government should design an effective policy to increase investment in training programs for labor and technical education.

\section{References}

Ackah, C. (2013). Nonfarm Employment and Incomes in Rural Ghana. Journal of International Development, 25(3), 325-339.

Acharya, C. P. And R. Gonzalez (2014) How Do Migration and Remittances Affect Human Capital Investment? The Effects of Relaxing Information and Liquidity Constraints. The Journal of Development Studies 50:3, 444-460.

Ali, S., Chaudhry, I, S., \& Farooq, F. (2012). Human Capital Formation and Economic Growth in Pakistan. Pakistan Journal of Social Sciences, 32, (1), 229-240.

Amin, A., Alam, D., \& Iqbal, N. (2020). Analysis of Factors Influencing Household Human Capital Investment Behavior in Conflict Zones: A Case Study of District Swat. Review of Economics and Development Studies, 6(4), 881-891.

Aref, A. (2011). Perceived Impact of Education on Poverty Reduction in Rural Areas of Iran. Life Science Journal, 8(2), 498-501.

Attanasio, O., Meghir, C., Nix, E., \& Salvati, F. (2017). Human Capital Growth and Poverty: Evidence from Ethiopia and Peru. Review of Economic Dynamics, 25, 234-259.

Atiq-ur-Rehman, M., Ghaffar, S., Shahzadi, K., \& Ghazanfar, R. (2020). Human Capital Formation and Economic Growth in Emerging Asia: Empirical Evidence Using Panel Data. Review of Applied Management \& Social Science, 3(2), 205-212.

Azam, M., \& Raza, S. A. (2016). Do Workers' Remittances Boost Human Capital Development? The Pakistan Development Review, 123-149.

Bansak, C., \& Chezum, B. (2009). How Do Remittances Affect Human Capital Formation of School-Age Boys and Girls? American Economic Review, 99(2), 145-48.

Becker, G. S. (1995). Human Capital and Poverty Alleviation. World Bank, Human Resources Development and Operations Policy.

Benhabib, J., \& Mark M. Spiegel. (1994). The Role of Human Capital in Economic Development: Evidence from Aggregate Cross-Country Data. Journal of Monetary Economics, 34, 143-173.

Blanchard, E. J., \& Olney, W. W. (2017). Globalization and Human Capital Investment: Export Composition Drives Educational Attainment. Journal of International Economics, 106, 165-183.

Chen, S., \& Wang, Y. (2001). China's Growth and Poverty Reduction: Recent Trends Between 1990 And 
1999. The Economist, 23.

Downey, D. B. (1995). When Bigger Is Not Better: Family Size, Parental Resources, And Children's Educational Performance? American Sociological Review, 746-761.

Handa, S., IMF, M. R. A., Stampini, M., \& Winters, P. (2005). Agricultural Subsidies, Human Capital Development and Poverty Reduction: Evidence from Rural Mexico. Department of Public Policy, University of North Carolina, Unpublished.

Hines, A. L., \& Simpson, N. B. (2019). Migration, Remittances and Human Capital Investment in Kenya. Economic Notes: Review of Banking, Finance and Monetary Economics, 48(3), E12142.

Jung, H. S., \& Thorbecke, E. (2003). The Impact of Public Education Expenditure On Human Capital, Growth, And Poverty in Tanzania and Zambia: A General Equilibrium Approach. Journal of Policy Modeling, 25(8), 701-725.

Khan, R., \& Chaudhry, I. S. (2019). Impact of human capital on employment and economic growth in developing countries. Review of Economics and Development Studies, 5(3), 487-496.

Knowles, S., \& Owen, P. D. (1995). Health Capital and Cross-Country Variation in Income Per Capita in The Mankiw-Romer-Weil Model. Economics Letters, 48(1), 99-106.

Knowles, Stephen, Paula K. Lorgelly, And P. Dorian Owen (2002) "Are Educational Gender Gaps a Brake on Economic Development? Some Cross-Country Empirical Evidence", Oxford Economic Papers, 54(1): 118-149.

Lee, J. W., \& Francisco, R. H. (2010). Human Capital Accumulation in Emerging Asia, 1970-2030. Asian Development Bank Economics Working Paper Series, (216).

Lee, J. W., \& Lee, H. (2016). Human Capital in The Long Run. Journal of Development Economics, 122, 147-169.

Lucas R. (1988). On The Mechanics of Economic Development. Journal of Monetary Economics, 22, 342 .

Mcfadden, D. (2008). Human Capital Accumulation and Depreciation. Review of Agricultural Economics, 30(3), 379-385.

Mincer, J. (1981). Human Capital and Economic Growth (No. Wo803). National Bureau of Economic Research.

Mukherjee, S., \& Benson, T. (2003). The Determinants of Poverty in Malawi, 1998. World Development, 31(2), 339-358.

Nguyen, H. M., \& Nguyen, T. A. (2019). Investigating the Determinants of Household Welfare in The Central Highland, Vietnam. Cogent Economics \& Finance, 7(1), 1684179.

Oketch, M, O. (2006). Determinants of Human Capital Formation and Economic Growth of African Countries. Economics of Education Review, 25, 554-564.

Olaniyan, D. A., \& Okemakinde, T. (2008). Human Capital Theory: Implications for Educational Development. Pakistan Journal of Social Sciences, 5(5), 479-483.

Romer P. (1986). Increasing Returns and Long Run Growth. Journal of Political Economy, 94(2), 10021037.

Sumberg, J., Gilbert, E., \& Blackie, M. (2004). Income Diversity, Technology Choice and Agricultural Research Policy in Sub-Saharan Africa. Development Policy Review, 22(2), 131-146.

Wang, Y., \& Liu, S. (2016). Education, Human Capital and Economic Growth: Empirical Research On 55 Countries and Regions (1960-2009). Theoretical Economics Letters, 6(02), 347.

Warren, M. R., Thompson, J. P., \& Saegert, S. (2001). The Role of Social Capital in Combating Poverty. Social Capital and Poor Communities, 3, 1-28.

Zhang, H. (2014). The Poverty Trap of Education: Education-Poverty Connections in Western China. International Journal of Educational Development, 38, 47-58. 